\title{
RECENT FINDINGS ON PERINATAL MESENCHYMAL STEM CELLS - THEIR POSSIBLE APPLICATION IN CURRENT ADVANCED MEDICINE
}

\author{
Rafał Sibiak ${ }^{1,2}$, Katarzyna Stefańska ${ }^{1}$, Kornel Ratajczak ${ }^{3}$, Dorota Bukowska ${ }^{4}$, Paweł Antosik ${ }^{3}$, Paul \\ Mozdziak $^{5,6}$, Michal Jeseta ${ }^{7,8}$
}

\begin{abstract}
The mature human placenta and umbilical cord are rich sources of perinatal mesenchymal stem cells (MSCs). Both cell populations have similar characteristics and cellular properties. Each population can differentiate into multiple mesenchymal subpopulations and retain their self-renewal capacities. Perinatal stem cells can be isolated from tissues obtained from the planned cesarean sections and vaginal deliveries. Their isolation is relatively easy, making them readily available for implementation in various in vitro studies and clinical trials. Their differentiation abilities could be used in advanced regenerative medicine protocols to form new bone, cartilage, or tendons. Moreover, their unique anti-inflammatory and immunomodulatory properties have been implemented in the experimental treatment of multiple autoimmune and degenerative diseases. Numerous phase I/II clinical trials confirmed the safety of perinatal MSCs injections and infusions, albeit the efficacy of those cellular therapies should be investigated in the subsequent large-scale randomized trials.
\end{abstract}

Running title: Clinical applications of the perinatal mesenchymal stem cells

Keywords: human, perinatal mesenchymal stem cells, placental mesenchymal stem cells, umbilical cord mesenchymal stem cells

\footnotetext{
${ }^{1}$ Department of Histology and Embryology, Poznań University of Medical Sciences, Poznań, Poland

${ }^{2}$ Department of Reproduction, Chair of Obstetrics, Gynecology, and Gynecologic Oncology, Poznań University of Medical Sciences, Poznań, Poland

${ }^{3}$ Department of Veterinary Surgery, Nicolaus Copernicus University in Toruń, Toruń, Poland

${ }^{4}$ Department of Diagnostics and Clinical Sciences, Nicolaus Copernicus University in Toruń, Toruń, Poland

${ }^{5}$ Physiology Graduate Program, North Carolina State University, Raleigh, USA

${ }^{6}$ Prestage Department of Poultry Science, North Carolina State University, Raleigh, USA

${ }^{7}$ Department of Obstetrics and Gynecology, Faculty of Medicine, Masaryk University and University Hospital Brno, Brno, Czech Republic

${ }^{8}$ Department of Veterinary Sciences, Czech University of Life Sciences in Prague, Prague, Czech Republic

* Correspondence: jeseta@gmail.com

Full list of author information is available at the end of article
} 


\section{Introduction}

The placenta is a multifunctional fetomaternal organ. Its maternal part, decidua basalis, originates from the modified cells that form the uterine cavity's internal mucosal layer. The trophoblast cells penetrate into the decidualized uterus and form complex structures composed of cytotrophoblast and syncytiotrophoblast cells, known as the placental villi. The placental villus's core contains fetal blood vessels and is abundant in fetal mesenchymal tissue [1,2]. The placental mesenchymal tissue is rich in cells that possess high cellular plasticity and self-renewal capacities. Those cell populations are commonly known as placental mesenchymal stem cells (MSCs) [3]. The isolation of placental MSCs is feasible to be conducted from the samples of the mature placental tissue. Most healthcare facilities treat the normal mature placental tissue obtained after the cesarean section or the vaginal delivery as common medical waste. Based on that, the placental tissue samples' collection does not raise any critical ethical issues [4]. To summarize, the source of placental mesenchymal stem cells is readily available, and the isolated cells could be used for a range of experimental analyses.

According to the definition stated by participants of the First International Workshop on Placenta-derived Stem Cells, the placental MSCs include two different cellular subpopulations - the population of human amniotic mesenchymal stromal cells (hAM$\mathrm{SC}$ ) and the lineage of the human chorionic mesenchymal stromal cells (hCMSC) [5]. Both mentioned cellular populations could be relatively easily isolated from the amniotic membranes and chorionic tissue, respectively [6-8]. Moreover, both subpopulations exhibit similar cellular plasticity. It was reported that under specific environmental conditions, they could differentiate into various mesenchymal derivatives such as adipocytes, chondrocytes, and osteoblasts $[9,10]$. Also, the Wharton's jelly-derived MSCs express the stem cells marker genes (Oct-4, Nanog, and Sox-2) and differentiate into multiple mesodermal cell lineages [11]. Both the placental and Wharton's jelly MSCs properties can be applied in various innovative treatment protocols, especially in the fields of regenerative medicine and the treatment of chronic inflammatory diseases [12]. There are several different therapeutic approaches for the implementation of MSCs in daily clinical practice. It is believed that MSCs can directly build up the new bone or cartilage tissues and promote their formation. Their unique anti-inflammatory and regenerative capacities are thought to be associated with their specific secretory profiles. Excreting numerous anti-inflammatory cytokines, they can modify the local and systemic immune response that the facilitates tissue regeneration processes [13].

\section{Methodology}

PubMed and Scopus databases were searched for relevant references from the first records until February 2021, using the following terms: "perinatal stem cells", "placenta stem cells", "placental mesenchymal stem cells", "placenta-derived mesenchymal stem cells", "umbilical cord stem cells", "umbilical cord mesenchymal stem cells", and "umbilical cord-derived mesenchymal stem cells".

\section{Application of the perinatal stem cells in advanced medicine}

The experience gained from the numerous in vitro studies paves the way to the first experimental clinical trials focusing on the safety and efficacy of those novel cellular treatment strategies. Nonetheless, it should be emphasized that there are some limitations of those studies. The fact that many authors use various tissue preparation and cell separation protocols can lead to significant discrepancies between the analyzed trials. Also, the differences in cell doses and tissue source can modify the outcomes $[14,15]$. For example, Kong et al. revealed that the Wharton's jelly MSCs obtained from the mothers with gestational diabetes exhibited significantly lower cell proliferation, expression of stemness markers and genes regulating the mitochondrial function, and presented decreased osteogenic and chondrogenic potential compared with the control group [16]. Nonetheless, numerous promising reports indicate that the perinatal MSCs administration is safe and can markedly improve a range of clinical parameters and enhance the patients' quality of life.

\section{Placenta-derived mesenchymal stem cells}

It is believed that placenta-derived MSCs open novel perspectives for cellular therapies in regenerative medicine. Soltani et al., in their pilot study, noted that the single intra-articular placental MSCs injection in patients with knee osteoarthritis is safe and could significantly improve the patients' quality of life, knee flexion range of motion, and alleviate the pain (Tab. 1) [17]. Winkler et al. used a hip arthroplasty surgery as a model of skeletal muscle injury. Their randomized-controlled trial revealed that the patients who received placental MSCs intramuscular injection reached significantly increased muscle strength and muscle volume compared with controls. They did not observe any acute and long-term treatment-related adverse effects [15]. Ji et al. discovered that the conditioned medium from placenta-derived MSCS increased the proliferation and lowered the apoptosis rate in human periodontal ligament stem cells obtained from the extracted premolars [18]. Moreover, placenta-derived MSCs hydrogel appeared as a novel therapeutic option for patients with diabetic foot ulcers. 
TABLE 1. Application of perinatal MSCs in human clinical trials

\begin{tabular}{|c|c|c|c|c|}
\hline $\begin{array}{l}\text { STUDY TITLE } \\
\text { [REFERENCE] }\end{array}$ & TYPE OF STUDY & \begin{tabular}{|c|} 
NUMBER OF \\
PARTICIPANTS
\end{tabular} & $\begin{array}{l}\text { MEDICAL } \\
\text { CONDITION }\end{array}$ & $\begin{array}{c}\text { FIRST } \\
\text { AUTHOR, } \\
\text { (YEAR) }\end{array}$ \\
\hline $\begin{array}{c}\text { Immunomodulatory placental-expand- } \\
\text { ed, mesenchymal stromal cells improve } \\
\text { muscle function following hip arthroplas- } \\
\text { ty. [15] }\end{array}$ & $\begin{array}{l}\text { Randomized, do- } \\
\text { uble blind, and } \\
\text { placebo-controlled, } \\
\text { phase I/IIa study }\end{array}$ & 20 & $\begin{array}{l}\text { Skeletal muscle } \\
\text { injury - hip arthro- } \\
\text { plasty model }\end{array}$ & $\begin{array}{l}\text { Winkler, } \\
\text { (2018) }\end{array}$ \\
\hline $\begin{array}{l}\text { Safety and efficacy of allogenic placental } \\
\text { mesenchymal stem cells for treating knee } \\
\text { osteoarthritis: a pilot study. [17] }\end{array}$ & $\begin{array}{l}\text { Randomized, control- } \\
\text { led, double-blind } \\
\text { clinical trial }\end{array}$ & 20 & Knee osteoarthritis & $\begin{array}{l}\text { Soltani, } \\
\text { (2018) }\end{array}$ \\
\hline $\begin{array}{l}\text { Determining the feasibility of managing } \\
\text { erectile dysfunction in humans with } \\
\text { placental-derived stem cells. [20] }\end{array}$ & $\begin{array}{l}\text { Prospective, non-con- } \\
\text { trolled, phase I clinical } \\
\text { trial }\end{array}$ & 8 & $\begin{array}{c}\text { Erectile } \\
\text { dysfunction }\end{array}$ & $\begin{array}{l}\text { Levy, } \\
\text { (2016) }\end{array}$ \\
\hline $\begin{array}{l}\text { Placenta-derived mesenchymal-like cells } \\
\text { (PDA-001) as therapy for chronic pulmo- } \\
\text { nary sarcoidosis: a phase } 1 \text { study. [23] }\end{array}$ & $\begin{array}{l}\text { Prospective, non-con- } \\
\text { trolled, single-center, } \\
\text { open-label phase I trial }\end{array}$ & 4 & $\begin{array}{l}\text { Chronic pulmonary } \\
\text { sarcoidosis }\end{array}$ & $\begin{array}{c}\text { Baughman, } \\
\text { (2015) }\end{array}$ \\
\hline $\begin{array}{l}\text { A phase } 1 \mathrm{~b} \text { study of placenta-derived me- } \\
\text { senchymal stromal cells in patients with } \\
\text { idiopathic pulmonary fibrosis. [24] }\end{array}$ & $\begin{array}{l}\text { Single center, non-ran- } \\
\text { domized, dose escala- } \\
\text { tion phase Ib trial }\end{array}$ & 8 & $\begin{array}{l}\text { Idiopathic pulmo- } \\
\text { nary fibrosis }\end{array}$ & $\begin{array}{c}\text { Chambers, } \\
\text { (2014) }\end{array}$ \\
\hline $\begin{array}{l}\text { Transplantation of placenta-derived me- } \\
\text { senchymal stem cells in type } 2 \text { diabetes: } \\
\text { a pilot study. [28] }\end{array}$ & $\begin{array}{l}\text { Prospective, non-con- } \\
\text { trolled, phase I clinical } \\
\text { trial }\end{array}$ & 10 & Type 2 diabetes & $\begin{array}{l}\text { Jiang, } \\
(2011)\end{array}$ \\
\hline $\begin{array}{l}\text { Human placenta-derived cells (PDA-001) } \\
\text { for the treatment of adults with multiple } \\
\text { sclerosis: a randomized, placebo-control- } \\
\text { led, multiple-dose study. [31] }\end{array}$ & $\begin{array}{l}\text { Multicenter, rando- } \\
\text { mized, double-blind, } \\
\text { placebo-controlled, } \\
\text { 2-dose ranging, phase } \\
\text { Ib study }\end{array}$ & 16 & Multiple sclerosis & $\begin{array}{l}\text { Lublin, } \\
\text { (2014) }\end{array}$ \\
\hline $\begin{array}{c}\text { Safety and efficacy of the intravenous } \\
\text { infusion of umbilical cord mesenchymal } \\
\text { stem cells in patients with heart failure: } \\
\text { a phase } 1 / 2 \text { randomized controlled trial } \\
\text { (rimecard trial [randomized clinical trial } \\
\text { of intravenous infusion umbilical cord } \\
\text { mesenchymal stem cells on cardiopa- } \\
\text { thy]). [34] }\end{array}$ & $\begin{array}{c}\text { Randomized, controlled } \\
\text { trial, Phase I/II }\end{array}$ & 30 & $\begin{array}{l}\text { Chronic stable } \\
\text { heart failure and } \\
\text { reduced ejection } \\
\text { fraction }\end{array}$ & $\begin{array}{c}\text { Bartolucci, } \\
\text { (2017) }\end{array}$ \\
\hline $\begin{array}{c}\text { Effect of intramyocardial grafting colla- } \\
\text { gen scaffold with mesenchymal stromal } \\
\text { cells in patients with chronic ischemic } \\
\text { heart disease: a randomized clinical trial. } \\
{[35]} \\
\end{array}$ & $\begin{array}{l}\text { Randomized, double- } \\
\text {-blind clinical trial }\end{array}$ & 50 & $\begin{array}{c}\text { Chronic ischemic } \\
\text { heart disease }\end{array}$ & $\begin{array}{l}\mathrm{He}, \\
(2020)\end{array}$ \\
\hline $\begin{array}{c}\text { Umbilical cord-derived mesenchymal } \\
\text { stromal cells (MSCs) for knee osteoar- } \\
\text { thritis: repeated MSC dosing is superior } \\
\text { to a single MSC dose and to hyaluronic } \\
\text { acid in a controlled randomized phase I/ } \\
\text { II trial. [36] }\end{array}$ & $\begin{array}{l}\text { Randomized, control- } \\
\text { led, phase I/II trial }\end{array}$ & 26 & Knee osteoarthritis & $\begin{array}{l}\text { Matas, } \\
(2019)\end{array}$ \\
\hline $\begin{array}{c}\text { Efficacy and safety of umbilical cord } \\
\text { mesenchymal stem cell therapy for rheu- } \\
\text { matoid arthritis patients: a prospective } \\
\text { phase I/II study. [38] }\end{array}$ & $\begin{array}{l}\text { Prospective phase I/II } \\
\text { study }\end{array}$ & 64 & $\begin{array}{l}\text { Rheumatoid } \\
\text { arthritis }\end{array}$ & $\begin{array}{l}\text { Wang, } \\
(2019)\end{array}$ \\
\hline $\begin{array}{l}\text { Umbilical cord mesenchymal stem cell } \\
\text { treatment for Crohn's disease: a rando- } \\
\text { mized controlled clinical trial. [41] }\end{array}$ & $\begin{array}{c}\text { Randomized controlled } \\
\text { clinical trial }\end{array}$ & 82 & Crohn's disease & $\begin{array}{l}\text { Zhang, } \\
(2018)\end{array}$ \\
\hline
\end{tabular}




\begin{tabular}{|c|c|c|c|c|}
\hline $\begin{array}{l}\text { STUDY TITLE } \\
\text { [REFERENCE] }\end{array}$ & TYPE OF STUDY & $\begin{array}{c}\text { NUMBER OF } \\
\text { PARTICIPANTS }\end{array}$ & $\begin{array}{l}\text { MEDICAL } \\
\text { CONDITION }\end{array}$ & $\begin{array}{l}\text { FIRST } \\
\text { AUTHOR, } \\
\text { (YEAR) }\end{array}$ \\
\hline $\begin{array}{l}\text { Clinical feasibility of umbilical cord tissu- } \\
\text { e-derived mesenchymal stem cells in the } \\
\text { treatment of multiple sclerosis. [42] }\end{array}$ & $\begin{array}{c}\text { Open-label, single-arm, } \\
\text { single-center phase I/ } \\
\text { II trial }\end{array}$ & 20 & Multiple sclerosis & $\begin{array}{l}\text { Riordan, } \\
\text { (2018) }\end{array}$ \\
\hline $\begin{array}{l}\text { Allogeneic mesenchymal stem cells as } \\
\text { induction therapy are safe and feasible in } \\
\text { renal allografts: pilot results of a multi- } \\
\text { center randomized controlled trial. [43] }\end{array}$ & $\begin{array}{l}\text { Multicenter randomi- } \\
\text { zed controlled trial }\end{array}$ & 42 & $\begin{array}{c}\text { Renal } \\
\text { transplantation }\end{array}$ & $\begin{array}{l}\text { Sun, } \\
\text { (2018) }\end{array}$ \\
\hline $\begin{array}{l}\text { A pilot study of mesenchymal stem cell } \\
\text { therapy for acute liver allograft rejection. } \\
\text { [44] }\end{array}$ & $\begin{array}{c}\text { Randomized, controlled } \\
\text { trial }\end{array}$ & 27 & $\begin{array}{l}\text { Acute liver allo- } \\
\text { graft rejection }\end{array}$ & $\begin{array}{l}\text { Shi, } \\
\text { (2017) }\end{array}$ \\
\hline $\begin{array}{l}\text { Allogeneic cell therapy using umbilical } \\
\text { cord MSCs on collagen scaffolds for } \\
\text { patients with recurrent uterine adhesion: } \\
\text { a phase I clinical trial. [45] }\end{array}$ & $\begin{array}{l}\text { Prospective, non-con- } \\
\text { trolled, phase I clinical } \\
\text { trial }\end{array}$ & 26 & $\begin{array}{l}\text { Infertility cau- } \\
\text { sed by recurrent } \\
\text { intrauterine } \\
\text { adhesions }\end{array}$ & $\begin{array}{l}\text { Cao, } \\
(2018)\end{array}$ \\
\hline $\begin{array}{l}\text { Umbilical cord-derived mesenchymal } \\
\text { stem (stromal) cells for treatment of } \\
\text { severe sepsis: aphase } 1 \text { clinical trial. [47] }\end{array}$ & $\begin{array}{l}\text { Single-center, open- } \\
\text {-label, dose-escalation } \\
\text { phase I clinical trial }\end{array}$ & 15 & Severe sepsis & $\begin{array}{c}\mathrm{He}, \\
(2018)\end{array}$ \\
\hline $\begin{array}{l}\text { Human umbilical cord-derived mesen- } \\
\text { chymal stem cell therapy in patients with } \\
\text { COVID-19: a phase } 1 \text { clinical trial. [48] }\end{array}$ & $\begin{array}{c}\text { Parallel assigned } \\
\text { controlled, non-rando- } \\
\text { mized, phase I clinical } \\
\text { trial }\end{array}$ & 18 & COVID-19 & $\begin{array}{l}\text { Meng, } \\
(2020)\end{array}$ \\
\hline $\begin{array}{l}\text { Treatment of severe COVID-19 with hu- } \\
\text { man umbilical cord mesenchymal stem } \\
\text { cells. [49] }\end{array}$ & $\begin{array}{l}\text { Single-center open-la- } \\
\text { bel, individually } \\
\text { randomized, standard } \\
\text { treatment-controlled } \\
\text { trial }\end{array}$ & 41 & COVID-19 & $\begin{array}{l}\text { Shu, } \\
(2020)\end{array}$ \\
\hline
\end{tabular}

Zeng et al. described a case of chronic injury in which the conventional therapies were ineffective. The application of placenta-derived MSCs hydrogel improved wound healing and restored the foot's functionality [19]. Levy et al. injected a solution of placental MSCs into the base of each corpora cavernosum in patients with severe erectile dysfunction. Their outcomes indicate that the intrapenile MSCs injection increased the local blood flow by increasing the peak systolic velocity. Nonetheless, they did not note significant changes in end-diastolic velocity, stretched penile length, penile width, and the erectile function scores [20,21]. Finally, the observations gained from the mouse model of radiation enteropathy suggest that the human placenta-derived MSCs can be used in the prophylactics and treatment of radiation injury [22].

It is believed that the immunomodulatory properties of placental MSCs can modify the course of chronic inflammatory diseases. Baughman et al. administered the placental MSCs treatment in four patients with chronic pulmonary sarcoidosis. After 1-year follow-up, patients did not improve their spirometric pulmonary function parameters. However, two patients discontinued prednisone ther- apy due to significant chest $\mathrm{x}$-ray improvements [23]. Chambers et al. determined the efficiency of placental MSCs infusion in patients with idiopathic pulmonary fibrosis. They discovered that at six months after the procedure, the patients' diffusing capacity for carbon monoxide, forced vital capacity, 6-minute walk distance, and tomography fibrosis score were unchanged [24]. Lin et al. examined the possible placental MSCs' activity in asthma. They collected blood samples from children patients and assessed the influence of MSCs on the T cells activation and proliferation and the IL-5 concentrations in vitro. They discovered that the CD4+ and CD8+ $\mathrm{T}$ cells' activation and proliferation and IL-5 levels were significantly decreased in cultures with MSCs. These results suggest that placental-derived MSCs therapy can inhibit inflammation in children with asthma [25]. Park et al. analyzed the possible application of placental MSCs in the treatment of Grave's ophthalmopathy. They found that the MSCs can inhibit the lipid accumulation in orbital fibroblasts obtained from the patients with Graves' disease in vitro [26]. Chronic inflammatory bowel diseases e.g., Crohn's disease and colitis ulcerosa - are liable 
for the increased intestinal fibrosis. Choi et al. examined how the placental or umbilical cord-derived MSCs could affect the function of intestinal myofibroblasts. They discovered that MSCs reduced the TGF- $\beta 1$-induced expression of profibrotic mediators (RhoA, MRTF-A, and SRF) in human primary intestinal myofibroblasts in vitro [27]. Jiang et al. reported that the serial intravenous infusions of placental-derived MSCs are safe and can significantly improve the islets' function in type 2 diabetes patients. They observed a mean 2-fold decrease in daily insulin dose and increased C-peptide concentrations in patients who received the cell infusions [28].

Furthermore, placenta-derived MSCs therapy is promising in various degenerative diseases. It has been speculated that placental MSCs' exosomes are responsible for their biological activity [29]. Bier et al. reported that the myoblasts treated with the placental MSCs conditioned medium or isolated exosomes increased their differentiation and decreased the expression of fibrogenic genes in samples collected from patients with Duchenne muscular dystrophy, possibly via delivery of exosomal miR-29c molecules [30]. Lublin et al. assessed the feasibility and efficiency of placental-derived MSCs infusion in patients with multiple sclerosis. During the observation after MSCs administration, the vast majority of the patients had stable or decreasing Expanded Disability Status Scale score. The authors observed one anaphylactoid reaction in their study population [31]. Liu et al. discovered that the transplantation of human placenta-derived MSCs reduces renal injury in a mouse model of lupus nephritis. They reported that the MSCs injections decreased the proteinuria, synthesis of specific anti-dsDNA antibodies, and expression of several pro-inflammatory cytokines [32].

\section{Umbilical cord-derived mesenchymal stem cells}

The regenerative properties of umbilical cord MSCs were examined in numerous clinical trials. Hashemi et al. found that the administration of Wharton's jelly MSCs seeded on acellular amniotic membranes promotes the healing of chronic diabetic wounds. They noted that the wound size significantly decreased after 6 to 9 days of cellular therapy [33]. Bartolucci et al. discovered that umbilical cord MSCs infusion increased the left ventricular ejection fraction assessed through transthoracic echocardiography and cardiac MRI in patients with chronic stable heart failure and reduced ejection fraction. They reported that their patients experienced significant functional status and quality of life improvement [34]. He et al. examined the safety and feasibility of umbilical cord MSCs-laden collagen hydrogel intramyocardial injections in patients with chronic ischemic heart disease. They did not observe any serious adverse effects of applied therapy. They noted a slight decrease in the mean infarct size change at 12 months after treatment [35]. Matas et al. evaluated the efficiency of intra-articular injections of umbilical cord-derived MSCs in knee osteoarthritis treatment. They found that patients treated with MSCs injections experienced significant functional and pain improvements from baseline, while the controls who received hyaluronic acid injections did not experience any change. However, they observed no between-group differences in MRI scores [36]. Chen et al. analyzed the efficacy of umbilical cord-derived MSCs-based therapy for osteonecrosis of the femoral head. They found that at 12 and 24 months after the procedure, the volume of necrotic changes has been significantly reduced [37]. Wang et al. assessed the long-term efficacy of umbilical cord MSCs infusions in patients with rheumatoid arthritis. They observed a reduction in the inflammatory markers and significantly improved joint function index - DAS28 - 1 year and 3 years after treatment [38].

The unique immunomodulatory properties of perinatal stem cells can be applied in the treatment of inflammatory and autoimmune diseases. Liang et al. analyzed the long-term safety profile of umbilical cord MSCs infusions in a large group of patients with various autoimmune diseases - main afflictions included systemic lupus erythematosus, Sjögren's syndrome, and systemic sclerosis. They concluded that the MSCs infusions are not associated with any severe long-term adverse effects in patients with autoimmune diseases [39]. A randomized controlled trial conducted in patients with lupus nephritis revealed that the MSCs infusion administered as a supportive therapy is ineffective in that indication [40]. Zhang et al. administered four serial umbilical cord MSCs infusions to patients diagnosed with Crohn's disease. At 12 months after the treatment, patients who received the cell therapy showed a significantly higher decrease in the Crohn's disease activity index, Harvey-Bradshaw index, and the daily corticosteroid dosage compared with the control group [41]. Riordan et al. assessed the effects of the seven infusions of umbilical cord-derived MSCs in patients with multiple sclerosis. At 1 month after the treatment, they noted significant improvements in the expanded disability status scale; in the bladder, bowel, and sexual dysfunction; in non-dominant hand function, and the results of walk tests [42]. Sun et al. hypothesized that umbilical cord MSCs could be implemented as efficient induction therapy in patients who undergo renal transplantation because of their anti-inflammatory and immunomodulatory properties. The patients received peripheral MSCs infusion before the transplantation and the second cell dosages via the renal artery during the surgery. The graft recipients well tolerated the MSCs infusions. Nevertheless, larger trials are needed to prove their efficacy in improving the delayed graft function or acute rejection incidence 
[43]. Shi et al. assessed the role of umbilical cord MSCs infusions in patients with acute liver allograft rejection. In control measures - 4 weeks after the intervention - they observed the significant decrease in alanine aminotransferase levels and the increase in the $\mathrm{T}$ regulatory cells/T helper cells ratio, as well as the TGF- $\beta 1$ and prostaglandin E2 concentrations. Those findings suggest that perinatal MSCs could potentially suppress acute graft rejection [44].

Cao et al. performed the intrauterine transplantations of umbilical cord MSCs loaded onto collagen scaffolds in patients with infertility caused by recurrent intrauterine adhesions. They discovered that three months after the MSCs transplantation, the intrauterine adhesion score decreased, and average endometrial thickness increased compared with pre-treatment evaluation results. At the end of the 30-month follow-up period, 8 out of 26 study participants delivered live infants. The treatment did not cause any serious adverse effects [45]. Ding et al. reported that the intraovarian transplantation of umbilical cord MSCs loaded onto collagen scaffolds into women diagnosed with premature ovarian failure could restore ovarian functionality. After the MSCs injection, they noted the increase in the estradiol concentrations and observed the follicles' development by sonography. Moreover, after the procedure, two patients with a long history of infertility conceived without any advanced technology [46].

It has been hypothesized that the MSCs infusions could be used as a novel method of treatment for patients with serious infections. He et al. examined the safety of umbilical cord MSCs administration in patients with severe sepsis. Testing the effects of various cell dosages, they found no adverse effects of umbilical cord MSCs infusions in patients with sepsis [47]. Some authors proved the safety of umbilical cord MSCs infusions in patients with moderate and severe COVID-19 pulmonary disease $[48,49]$. Shu et al. reported that the infusion of human umbilical cord MSCs shortens the time to clinical improvement in patients with COVID-19. Furthermore, patients treated with MSCs had lower CRP and IL-6 levels from day 3 of infusion and experienced faster normalization of lymphocyte count and absorption of lung inflammation features observed on CT imaging [49].

\section{Conclusions}

In summary, numerous experimental studies and clinical trials focused on the potential implementations of perinatal mesenchymal stem cells in novel treatment protocols. Whereas multiple studies confirmed the safety and feasibility of MSCs therapies, their efficacy should be further investigated in large-scale randomized trials. Nonetheless, the first reports indicate that the application of both placental and umbilical cord-derived MSCs can improve wound healing, tissue regeneration and modify the course of various autoimmune and degenerative diseases. Finally, it is crucial to establish homogenous tissue collection and cell preparation protocols to restrain these factors' influence on the clinical trials outcomes.

\section{Ethical approval}

The conducted research is not related to either human or animal use.

\section{Acknowledgments}

This publication and its results are an outcome of a cooperation between Poznan University of Medical Sciences (Poznań, Poland) and Polish Ministry of Science and Higher Education, with Cellivia 3 SA (Poznań, Poland), as a part of the "Professional PhD" program.

\section{Corresponding author}

Asss. prof. Ješeta Michal, Ph.D., Department of Obstetrics and Gynecology, University Hospital and Masaryk University, Obilni trh 11, 60200 Brno, Czech Republic, e-mail: jeseta@gmail.com.

\section{Conflict of interest statement}

The authors declare they have no conflict of interest.

\section{References}

1. Huppertz B. The anatomy of the normal placenta. J Clin Pathol 2008;61:1296-302; DOI:10.1136/jcp.2008.055277.

2. Aplin JD, Myers JE, Timms K, Westwood M. Tracking placental development in health and disease. Nat Rev Endocrinol. 2020;16:479-94; DOI:10.1038/s41574-020-0372-6.

3. Fukuchi Y, Nakajima H, Sugiyama D, Hirose I, Kitamura T, Tsuji K. Human Placenta-Derived Cells Have Mesenchymal Stem/Progenitor Cell Potential. Stem Cells. 2004;22:649-58; DOI:10.1634/stemcells.22-5-649.

4. Huang Q, Yang Y, Luo C, Wen Y, Liu R, Li S, Chen T, Sun H, Tang L. An efficient protocol to generate placental chorionic plate-derived mesenchymal stem cells with superior proliferative and immunomodulatory properties. Stem Cell Res Ther. 2019;10:301; DOI:10.1186/ s13287-019-1405-8.

5. Parolini O, Alviano F, Bagnara GP, Bilic G, Bühring H-J, Evangelista M, Hennerbichler S, Liu B, Magatti M, Mao N, Miki T, Marongiu F, Nakajima H, Nikaido T, Portmann-Lanz CB, Sankar V, Soncini M, Stadler G, Surbek D, Takahashi TA, Redl H, Sakuragawa N, Wolbank S, Zeisberger S, Zisch A, Strom SC. Concise Review: Isolation and Characterization of Cells from Human Term Placenta: Outcome of the First International Workshop on Placenta Derived Stem Cells. Stem Cells. 2008;26:300-11; DOI:10.1634/ stemcells.2007-0594.

6. Papait A, Vertua E, Magatti M, Ceccariglia S, De Munari S, Silini AR, Sheleg M, Ofir R, Parolini O. Mesenchymal Stromal Cells from Fetal and Maternal Placenta Possess Key Similarities and Differences: Potential Implications for Their Applications in Regenerative Medicine. Cells. 2020;9:127; DOI:10.3390/cells9010127.

7. Komaki M, Numata Y, Morioka C, Honda I, Tooi M, Yokoyama N, Ayame H, Iwasaki K, Taki A, Oshima N, Morita I. Exosomes of human placenta-derived mesenchymal stem cells stimulate angiogenesis. Stem Cell Res Ther. 2017;8:219; DOI:10.1186/s13287-017-0660-

8. Magatti M, Pianta S, Silini A, Parolini O. Isolation, culture, and phenotypic characterization of mesenchymal stromal cells from the amniotic membrane of the human term placenta. Methods Mol. Biol. 2016;1416:23344; DOI:10.1007/978-1-4939-3584-0_13.

9. Shen C, Yang C, Xu S, Zhao H. Comparison of osteogenic differentiation capacity in mesenchymal stem cells derived from human amniotic membrane (AM), umbilical cord (UC), chorionic membrane (CM), and decidua (DC). Cell Biosci. 2019;9:17; DOI:10.1186/s13578-019-0281-3.

10. Ma J, Wu J, Han L, Jiang X, Yan L, Hao J, Wang H. Comparative analysis of mesenchymal stem cells derived from amniotic membrane, umbilical cord, and chorionic plate under serum-free condition. Stem Cell Res Ther. 2019;10:19; DOI:10.1186/s13287-018-1104-X.

11. Kim MJ, Shin KS, Jeon JH, Lee DR, Shim SH, Kim JK, Cha DH, Yoon TK, Kim GJ. Human chorionic-plate-derived mesenchymal stem cells and Wharton's jelly-derived mesenchymal stem cells: A comparative analysis of their potential as placenta-derived stem cells. Cell Tissue Res. 2011;346:53-64; DOI:10.1007/s00441-011-1249-8.

12. Silini AR, Masserdotti A, Papait A, Parolini O. Shaping the future of perinatal cells: Lessons from the past and interpretations of the present. Front Bioeng Biotechnol. 2019;7:75; DOI:10.3389/fbioe.2019.00075. 
13. Abumaree MH, Abomaray FM, Alshabibi MA, AlAskar AS, Kalionis B. Immunomodulatory properties of human placental mesenchymal stem/stromal cells. Placenta. 2017;59:87-95; DOI:10.1016/j. placenta.2017.04.003

14. Avercenc-Léger L, Guerci P, Virion JM, Cauchois G, Hupont S, Rahouadj R, Magdalou J, Stoltz JF, Bensoussan D, Huselstein C, Reppel L. Umbilical cord-derived mesenchymal stromal cells: Predictive obstetric factors for cell proliferation and chondrogenic differentiation. Stem Cell Res Ther 2017;8:161; DOI:10.1186/s13287-017-0609-z.

15. Winkler T, Perka C, von Roth P, Agres AN, Plage H, Preininger B, Pumberger M, Geissler S, Hagai EL, Ofir R, Pinzur L, Eyal E, Stoltenburg-Didinger G, Meisel C, Consentius C, Streitz M, Reinke P, Duda GN, Volk HD. Immunomodulatory placental-expanded, mesenchymal stromal cells improve muscle function following hip arthroplasty. J Cachexia Sarcopenia Muscle. 2018;9:880-897; DOI:10.1002/jcsm.12316.

16. Kong CM, Subramanian A, Biswas A, Stunkel W, Chong YS, Bongso A, Fong CY. Changes in Stemness Properties, Differentiation Potential, Oxidative Stress, Senescence and Mitochondrial Function in Wharton's Jelly Stem Cells of Umbilical Cords of Mothers with Gestational Diabetes Mellitus. Stem Cell Rev Reports. 2019;15:415-426; DOI:10.1007/ s12015-019-9872-y.

17. Khalifeh Soltani S, Forogh B, Ahmadbeigi N, Hadizadeh Kharazi H, Fallahzadeh K, Kashani L, Karami M, Kheyrollah Y, Vasei M. Safety and efficacy of allogenic placental mesenchymal stem cells for treating knee osteoarthritis: a pilot study. Cytotherapy. 2019;21:54-63; D0I:10.1016/j.jcyt.2018.11.003

18. Ji LL, Song G, Jiang LM, Liu Y, Ding ZJ, Zhuang XY, Chen X. Evaluation of conditioned medium from placenta-derived mesenchymal stem cells a a storage medium for avulsed teeth: An in vitro study. Dent Traumatol. 2021;37:73-80; DOI:10.1111/edt.12599.

19. Zeng X, Tang Y, Hu K, Jiao W, Ying L, Zhu L, Liu J, Xu J. Three-week topical treatment with placenta-derived mesenchymal stem cells hydrogel in a patient with diabetic foot ulcer: A case report. Med (United States) 2017;96:e9212; DOI:10.1097/MD.0000000000009212.

20. Levy JA, Marchand M, Iorio L, Cassini W, Zahalsky MP. Determining the feasibility of managing erectile dysfunction in humans with placental-derived stem cells. J Am Osteopath Assoc. 2016;116:e1-5; DOI:10.7556/ jaoa.2016.007.

21. Levy JA, Marchand M, Iorio L, Zribi G, Zahalsky MP. Effects of stem cell treatment in human patients with peyronie disease. J Am Osteopath Assoc. 2015;115:e8-13; DOI:10.7556/jaoa.2015.124.

22. Han YM, Park JM, Choi YS, Jin H, Lee YS, Han NY, Lee H, Hahm KB. The efficacy of human placenta-derived mesenchymal stem cells on radiation enteropathy along with proteomic biomarkers predicting a favorable response. Stem Cell Res Ther. 2017;8:105; DOI:10.1186/ s13287-017-0559-5.

23. Baughman RP, Culver DA, Jankovi V, Fischkoff S, Brockway G, Lower EE. Placenta-derived mesenchymal-like cells (PDA-001) as therapy for chronic pulmonary sarcoidosis: A phase 1 study. Sarcoidosis Vasc Diffus Lung Dis. 2015;32:106-14.

24. Chambers DC, Enever D, Ilic N, Sparks L, Whitelaw K, Ayres J, Yerkovich ST, Khalil D, Atkinson KM, Hopkins PMA. A phase 1b study of placenta-derived mesenchymal stromal cells in patients with idiopathic pulmonary fibrosis. Respirology. 2014;19:1013-8; DOI:10.1111/resp.12343.

25. Lin SC, Liou YM, Ling TY, Chuang YH, Chiang BL. Placenta-derived mesenchymal stem cells reduce the interleukin-5 level experimentally in children with asthma. Int J Med Sci. 2019;16:1430-1438; DOI:10.7150/ ijms.33590.

26. Park M, Banga JP, Kim GJ, Kim MY, Lew H. Human placenta-derived mesenchymal stem cells ameliorate orbital adipogenesis in female mice models of Graves' ophthalmopathy. Stem Cell Res Ther. 2019;10:246 DOI:10.1186/s13287-019-1348-0.

27. Choi YJ, Koo JB, Kim HY, Seo JW, Lee EJ, Kim WR, Cho JY, Hahm KB, Hong SP, Kim DH, Yoo JH. Umbilical cord/placenta-derived mesenchymal stem cells inhibit fibrogenic activation in human intestinal myofibroblasts via inhibition of myocardin-related transcription factor A. Stem Cell Res Ther. 2019;10:291; DOI:10.1186/s13287-019-1385-8.

28. Jiang R, Han Z, Zhuo G, Qu X, Li X, Wang X, Shao Y, Yang S, Han ZC Transplantation of placenta-derived mesenchymal stem cells in type 2 diabetes: A pilot study. Front Med China. 2011;5:94-100; DOI:10.1007/ s11684-011-0116-z.

29. Kumar P, Becker JC, Gao K, Carney RP, Lankford L, Keller BA, Herout K, Lam KS, Farmer DL, Wang A. Neuroprotective effect of placenta-derived mesenchymal stromal cells: role of exosomes. FASEB J. 2019;33:58365849; DOI:10.1096/fj.201800972R

30. Bier A, Berenstein P, Kronfeld N, Morgoulis D, Ziv-Av A, Goldstein H, Kazimirsky G, Cazacu S, Meir R, Popovtzer R, Dori A, Brodie C. Placenta-derived mesenchymal stromal cells and their exosomes exert therapeutic effects in Duchenne muscular dystrophy. Biomaterials. 2018;174:67-78; DOI:10.1016/j.biomaterials.2018.04.055.

31. Lublin FD, Bowen JD, Huddlestone J, Kremenchutzky M, Carpenter A, Corboy JR, Freedman MS, Krupp L, Paulo C, Hariri RJ, Fischkoff SA Human placenta-derived cells(pda-001) for the treatment of adults with multiple sclerosis: Arandomized,placebo-controlled, multiple-dose study. Mult Scler Relat Disord. 2014;3:696-704; DOI:10.1016/j. msard.2014.08.002

32. Liu J, Lu X, Lou Y, Cai Y, Cui W, Wang J, Nie P, Chen L, Li B, Luo P. Xenogeneic Transplantation of Human Placenta-Derived Mesenchymal Stem Cells Alleviates Renal Injury and Reduces Inflammation in a Mouse Model of Lupus Nephritis. Biomed Res Int. 2019;2019:9370919; DOI:10.1155/2019/9370919.

33. Hashemi SS, Mohammadi AA, Kabiri H, Hashempoor MR, Mahmoodi M, Amini M, Mehrabani D. The healing effect of Wharton's jelly stem cells seeded on biological scaffold in chronic skin ulcers: A randomized clinical trial. J Cosmet Dermatol. 2019;18:1961-1967; DOI:10.1111/jocd.12931.

34. Bartolucci J, Verdugo FJ, González PL, Larrea RE, Abarzua E, Goset C, Rojo P, Palma I, Lamich R, Pedreros PA, Valdivia G, Lopez VM, Nazzal C, Alcayaga-Miranda F, Cuenca J, Brobeck MJ, Patel AN, Figueroa FE Khoury M. Safety and efficacy of the intravenous infusion of umbilical cord mesenchymal stem cells in patients with heart failure: A phase $1 / 2$ randomized controlled trial (RIMECARD trial [Randomized clinical trial of intravenous infusion umbilical cord mesenchymal stem cells on cardiopathy]). Circ Res. 2017;121:1192-1204; D0I:10.1161/ CIRCRESAHA.117.310712.

35. He X, Wang Q, Zhao Y, Zhang H, Wang B, Pan J, Li J, Yu H, Wang L, Dai J, Wang D. Effect of Intramyocardial Grafting Collagen Scaffold With Mesenchymal Stromal Cells in Patients With Chronic Ischemic Heart Disease: A Randomized Clinical Trial. JAMA Netw Open. 2020;3:e2016236; DOI:10.1001/jamanetworkopen.2020.16236.

36. Matas J, Orrego M, Amenabar D, Infante C, Tapia-Limonchi R, Cadiz MI, Alcayaga-Miranda F, González PL, Muse E, Khoury M, Figueroa FE, Espinoza F. Umbilical Cord-Derived Mesenchymal Stromal Cells (MSCs) for Knee Osteoarthritis: Repeated MSC Dosing Is Superior to a Single MSC Dose and to Hyaluronic Acid in a Controlled Randomized Phase I/II Trial. Stem Cells Transl Med. 2019;8:215-224; DOI:10.1002/sctm.18-0053.

37. Chen C, Qu Z, Yin X, Shang C, Ao Q, Gu Y, Liu Y. Efficacy of umbilical cord-derived mesenchymal stem cell-based therapy for osteonecrosis of the femoral head: A three-year follow-up study. Mol Med Rep. 2016;14:4209-4215; DOI:10.3892/mmr.2016.5745

38. Wang L, Huang S, Li S, Li M, Shi J, Bai W, Wang Q, Zheng L, Liu Y. Efficacy and safety of umbilical cord mesenchymal stem cell therapy for rheumatoid arthritis patients: A prospective phase I/II study. Drug Des Devel Ther. 2019;13:4331-4340; DOI:10.2147/DDDT.S225613.

39. Liang J, Zhang H, Kong W, Deng W, Wang D, Feng X, Zhao C, Hua B, Wang H, Sun L. Safety analysis in patients with autoimmune disease receiving allogeneic mesenchymal stem cells infusion: A long-term retrospective study. Stem Cell Res Ther. 2018;9:312; DOI:10.1186/ s13287-018-1053-4

40. Deng D, Zhang P, Guo Y, Lim TO. A randomised double-blind, placebo-controlled trial of allogeneic umbilical cord-derived mesenchymal stem cell for lupus nephritis. Ann Rheum Dis. 2017;76:1436-1439; DOI:10.1136/annrheumdis-2017-211073.

41. Zhang J, Lv S, Liu X, Song B, Shi L. Umbilical cord mesenchymal stem cell treatment for Crohn's disease: A randomized controlled clinical trial. Gut Liver. 2018;12:73-78; DOI:10.5009/gnl17035.

42. Riordan NH, Morales I, Fernández G, Allen N, Fearnot NE, Leckrone ME Markovich DJ, Mansfield D, Avila D, Patel AN, Kesari S, Paz Rodriguez J. Clinical feasibility of umbilical cord tissue-derived mesenchymal stem cells in the treatment of multiple sclerosis. J Transl Med. 2018;16:57; DOI:10.1186/s12967-018-1433-7.

43. Sun Q, Huang Z, Han F, Zhao M, Cao R, Zhao D, Hong L, Na N, Li H, Miao B, Hu J, Meng F, Peng Y, Sun Q. Allogeneic mesenchymal stem cells as induction therapy are safe and feasible in renal allografts: Pilot results of a multicenter randomized controlled trial. J Transl Med. 2018;16:52 DOI:10.1186/s12967-018-1422-X.

44. Shi M, Liu Z, Wang Y, Xu R, Sun Y, Zhang M, Yu X, Wang H, Meng L, Su H, Jin L, Wang FS. A Pilot Study of Mesenchymal Stem Cell Therapy for Acute Liver Allograft Rejection. Stem Cells Transl Med. 2017;6:2053-2061 DOI:10.1002/sctm.17-0134

45. Cao Y, Sun H, Zhu H, Zhu X, Tang X, Yan G, Wang J, Bai D, Wang J, Wang L, Zhou Q, Wang H, Dai C, Ding L, Xu B, Zhou Y, Hao J, Dai J, Hu Y. Allogeneic cell therapy using umbilical cord MSCs on collagen scaffolds for patients with recurrent uterine adhesion: A phase i clinical trial. Stem Cell Res Ther. 2018:9:192; DOI:10.1186/s13287-018-0904-3.

46. Ding L, Yan G, Wang B, Xu L, Gu Y, Ru T, Cui X, Lei L, Liu J, Sheng X, Wang B, Zhang C, Yang Y, Jiang R, Zhou J, Kong N, Lu F, Zhou H, Zhao Y, Chen 
B, Hu Y, Dai J, Sun H. Transplantation of UC-MSCs on collagen scaffold activates follicles in dormant ovaries of POF patients with long history of infertility. Sci China Life Sci. 2018;61:1554-1565; DOI:10.1007/ s11427-017-9272-2.

47. He X, Ai S, Guo W, Yang Y, Wang Z, Jiang D, Xu X. Umbilical cord-derived mesenchymal stem (stromal) cells for treatment of severe sepsis: aphase 1 clinical trial. Transl Res. 2018;199:52-61; DOI:10.1016/j. trsl.2018.04.006.

48. Meng F, Xu R, Wang S, Xu Z, Zhang C, Li Y, Yang T, Shi L, Fu J, Jiang T, Huang L, Zhao P, Yuan X, Fan X, Zhang JY, Song J, Zhang D, Jiao Y, Liu L, Zhou C, Maeurer M, Zumla A, Shi M, Wang FS. Human umbilical cord-derived mesenchymal stem cell therapy in patients with COVID-19: a phase 1 clinical trial. Signal Transduct Target Ther. 2020;5:172; DOI:10.1038/ s41392-020-00286-5.

49. Shu L, Niu C, Li R, Huang T, Wang Y, Huang M, Ji N, Zheng Y, Chen X, Shi L, Wu M, Deng K, Wei J, Wang X, Cao Y, Yan J, Feng G. Treatment of severe COVID-19 with human umbilical cord mesenchymal stem cells. Stem Cell Res Ther. 2020;11:361; DOI:10.1186/s13287-020-01875-5. 